\title{
Technopopulism: The Emergence of a Discursive Formation
}

\author{
Marco Deseriis \\ Northeastern University, Boston, USA, m.deseriis@neu.edu, \\ http://neu.academia.edu/MarcoDeseriis
}

\begin{abstract}
This article contends that technopopulism is a discursive formation that emerges from the convergence of two preexisting discourses: populism and technolibertarianism. Whereas these discourses are historically distinct the 2008 financial crisis and the 2011 wave of struggles precipitated the political conditions for their intersection. Such convergence produces both tensions and possibilities. On the one hand, technopopulism engenders a radically participatory model of democracy, which is ultimately anti-institutional as citizens cooperate and engage in sophisticated decision-making without the mediation of professional politicians. On the other hand, the more electorally successful technopopulist parties are led by charismatic leaders who synthesize the positions that emerge from the netroots to mobilize them against the establishment. These two seemingly contradictory aspects precipitate in two variants of technopopulism: a leaderless-technocratic variant, which is derived from the open source mode of governance and from early experiments of the Global Justice Movement in networked self-government; and a leaderist-populist variant, which is more strictly focused on the electoral competition as an intrinsically hegemonic practice. The article concludes with a reflection on the discursive complementarity of these two variants.
\end{abstract}

Keywords: technopopulism, technolibertarianism, populism, electronic democracy, social media activism, Global Justice Movement, Free and Open Source Software, Podemos, Five Star Movement, Occupy

Technopopulism is the belief that the "government of the people, by the people, for the people" (Lincoln 1953 [1863]) is achievable by means of information communications technology. The term belief denotes here an ideology, not in the Marxian sense of false consciousness, but in the Althusserian sense of a set of ideas that have a material existence (Althusser 1971). Technopopulism can also be understood in Foucauldian terms as an emerging discourse (Foucault 1972), that is, as a body of knowledge, norms, attitudes, and practices that arise from the hybridization of two preexisting discourses: populism and technolibertarianism. Even though these discursive practices are historically separate, I contend that they have begun to converge after the global financial crisis of 2008 as widespread frustration at the ruling elites' mishandling of the crisis sparked international protest movements, and propelled a new generation of "technoparties" such as the Five Star Movement in Italy, Podemos in Spain, and the Pirate Party in Iceland.

The article distinguishes between two variants of technopopulism: a technocractic and leaderless variant, which pursues and enacts meritocratic forms of democratic participation; and a leaderist, more strictly populist, variant wherein charismatic leaders play a critical role in conferring unity and identity to their parties. The first tendency is materialized in the modes of governance of small technoparties such as the Pirate Parties, free and open source software development projects, open content communities, and the emerging discourse of Liquid Democracy. The nationalistpopulist tendency is most evident in Southern Europe, where mass parties such as 
Podemos and Five Star Movement have successfully combined charismatic leadership with participatory uses of networked media.

Each variant has a distinctive politics of its own. The leaderless-technocratic variant pursues an agonistic politics of forking, which is derived from the development process of Free and Open Source Software (FOSS). In the world of open source programming "forking" denotes the practice of duplicating the source code of a program to develop an alternate version of it. Because FOSS is by and large based on voluntary contributions, forks compete for the limited time and resources of software developers, who cannot contribute to all projects. In the context of online political deliberation and decision-making, however, duplicating a political initiative is not a zerosum game. On the contrary, as we will see, forking constitute the basis for organizing a common discursive space wherein different proposals compete before they get voted on.

The leaderist-nationalist variant of techno-populism also believes that networked participation is essential to the achievement of a fully realized democracy. But whereas the technocratic-leaderless variant attributes to the network itself the task of producing a shared political line, the leaderist-populist variant endows political leaders with the task of synthesizing different and conflicting positions that may emerge from the network. Drawing from Ronfeldt's definition of cyberocracy (1992) as rule by way of information I refer to this network-based centralized strategy as a cybercratic politics of unity that pits the people against the establishment.

Before turning to the two strands of technopopulism, the article reflects upon technolibertarianism as a stratified discursive formation that embeds contradictory elements. Because digital information is not only widely accessible but also easily exchangeable, editable, and actionable, the general cyberlibertarian dictum "information wants to be free" covers over different understandings of the value and function of information. Through the example of the SOPA-PIPA strike, the largest Internet protest ever organized, we will see how Internet activists are increasingly capable of cooperating remotely outside the boundaries of formal institutions. This self-organizing capacity of Internet users is a necessary condition of technopopulism, which begins when the networked coordination of thousands of Internet users threatens to displace a professional class of coordinators: the career politicians.

\section{Three Strands of Technolibertarianism: Capitalist, Communalist, and Activist}

Technolibertarianism (or cyber-libertarianism) is often referred to as an ideology that combines a blind faith in technological progress and free-market economics with a deep distrust in statist, bureaucratic, and hierarchical forms of authority. In "The Californian Ideology"-one of the first texts to identify this ideological formationCameron and Barbrook argue that cyber-libertarianism combines two seemingly contradictory attitudes: the freewheeling spirit of the hippies and anti-militarist ethos of the New Left with "the entrepreneurial zeal and can-do attitude championed by the Californian New Right" $(2014,26)$. Subsequent historical studies have outlined the critical influence of counterculture on software engineers of the 1960s and 1970s (Markoff 2005) and on inspirational figures of the New Economy such as Stewart Brand, Kevin Kelly, and Louis Rossetto (Turner 2006). ${ }^{1}$

${ }^{1}$ Fred Turner has added an important corrective to Cameron and Barbrook's analysis by noting that the Californian ideology was predicated on the disavowal of the social antagonism of the New Left and the subsumption of the "communalist" strand of the counterculture under "the computational metaphors and universal rhetoric of cybernetics" $(2006,209)$. Skeptical 
Technolibertarianism has undoubtedly an ideological dimension, which is epitomized by maxims such as "information wants to be free" (Brand 1985, 49) and "We reject: kings, presidents, and voting. We believe in: rough consensus and running code" (Clark 1992). This techno-utopian faith in the liberating, anti-authoritarian power of networked information technologies runs through prescient literary works on cyberspace (Gibson 1984) cyber-libertarian declarations, charters and manifestoes (Barlow 1996; Dyson et al. 1994; Levine et al. 2001), "musings" on software engineering methods (Raymond 1999), visionary magazines such as Wired and Mondo 2000, and studies on the emergent and self-organizing properties of distributed networks (Kelly 1994; Johnson 2001; Barabási 2002).

Whereas this purely ideological dimension should not be overlooked, cyberlibertarianism is also embedded and embodied in the daily practices and institutions of software engineers, FOSS programmers, amateur cryptographers, digital rights advocates, civic hackers, 3D makers, and open data, open content, and open hardware enthusiasts. In order to account for this material and institutional dimension, I propose to frame technolibertarianism as an hegemonic formation. I borrow this heuristic device from Laclau and Mouffe $(1985,136)$, who have combined the Gramscian notion of hegemony with Michel Foucault's discourse analysis to develop an analytic for contemporary social struggles. As is known, Foucault describes a discursive formation as a principle of "regularity in dispersion," that is, as an ensemble of differential positions whose cohesion is given by certain "rules of formation" (1972, 31-39). Combining Gramsci and Foucault, Laclau and Mouffe argue that an hegemonic (discursive) formation presupposes a unifying principle that establishes an equivalence among the differential positions of the ensemble in opposition to a common enemy $(1985,127-45)$.

In the case of cyberlibertarianism, such unifying principle rests with the practical belief that the unfettered circulation of information is conducive to freer societies and thus that actors who build their power on information scarcity will logically tend to limit access to information. Whereas this belief resonates with longstanding tenets of modern liberalism such as freedom of the press and freedom of speech (Coleman 2013), it is important to note that computer networks do not only democratize access to information but also make the latter more easily reproducible, exchangeable, editable, and actionable. In this sense, the cyberlibertarian dictum "information wants to be free" conflates different conceptions of the value, function, and purpose of information and thus different notions of freedom. From this angle, cyberlibertarianism is a stratified discursive formation, whose unifying principle is a generic notion of information freedom, but within which we can isolate at least three distinct strands:

1. A techno-capitalist strand, which sees information primarily as a commodity and asset. For this strand the most significant properties of digital information are its accessibility, reproducibility, and exchangeability. Indeed, the capacity of digital

that the antagonistic approach of the New Left and the anti-war movement could bring about any social change, some hippies had been attracted to the cybernetic vision of the world as a self-regulating pattern of information (Ibid, 4). Whereas such holistic view resonated with a longstanding "artistic critique" of capitalism as productive of alienation and dull existential conditions it was much less compatible with a "social critique" of capitalism as productive of exploitation and social inequality (Boltanski and Chiapello 2006). By coopting the former and discarding the latter, cyberlibertarianism was thus able to turn the freewheeling spirit of the counterculture into ideological fodder for the New Economy's promise of a society of free, autonomous, and cooperating individuals. 
technologies to encode a wide range of inputs into a highly reproducible format based on binary digits makes information a commodity that is universally exchangeable and saleable.

2. A communalist strand, which sees information primarily as a common good. For this strand not only is information valuable for its accessibility and reproducibility but also and foremost for its modifiability. A community that is able to fully share and modify information can develop common repositories of knowledge (e.g. Wikipedia, Github) and non-proprietary technologies (e.g. Linux) that fulfil a wide range of needs.

3. An activist strand, which sees information primarily as a public good. For this strand the most valuable properties of information are its accessibility and actionability. Accessibility allows a society to establish shared truths and validity claims without which ethical action would be impossible (Habermas 1984). Actionability allows a community to deliberate on issues of common concern and organize decision-making processes that make such deliberation possible.

Even though these three strands are clearly distinct, they share an opposition to two common enemies: the modern nation-state, with its arbitrary checks and stoppages on the otherwise free flow of goods, people, and information; and the industrial corporation, whose heavily centralized structure and market dominance hampers the emergence of a spontaneous system of market transactions (Levine et al. 2001). It follows that cyberlibertarians see the alliance between industrial corporationsespecially those that own large stocks of information-and the state as a major threat to information freedom. Such threat, however, has different implications for each strand. For the techno-capitalists such an alliance can limit their ability to extract value from the circulation of informational commodities. For the communalists, a restrictive intellectual property regime limits Internet users' capacity to edit and share information with one another. And for the activists, limiting access to information hampers the public's capacity to make informed decisions without which the free exercise of democracy is impossible. In the next section we will see how the threat posed by this alliance to the two most fundamental properties of digital informationits accessibility and reproducibility-sparked the unified response of the three strands in what came down in history as the largest Internet protest of all times.

\section{The Internet Blackout and the Problem of Networked Activism's Autonomy}

On January 18, 2012, thousands of Internet websites blackened their home pages and posted messages of protest against the approval of the Stop Online Piracy Act (SOPA) and Protect IP Act (PIPA). A coalition of major copyright owners in the music, film, and TV industries as well as the pharmaceutical industry had promoted the two bills at the U.S. Congress with the goal of allowing government to shut down the domain names of copyright infringing websites. In the matter of weeks, a coalition of cyber-rights activist groups banded together with tech companies and online communities to denounce the chilling effect of the bills on freedom of speech and block their approval. Whereas the idea of an Internet strike was not new, its scale was unprecedented. It is estimated that over 115,000 websites joined the protest. On January 18 alone 3 million emails were sent and over 100,000 phone calls were made to Congress to express opposition to the bills; 10 million people signed petitions; 2.4 million Tweets contained keywords related to the strike, and 8 million Internet users looked up their representative on Wikipedia (Wortham 2012a; Netburn 2012). Additionally, thousands of demonstrators protested in front of their representatives' offices 
across the United States. These combined actions induced lawmakers in both branches of Congress to shelve the bills on January 20, 2012.

The reasons of the overwhelming success of the Internet Blackout are easy to identify. If the strike was coordinated by a handful of digital rights advocacy groups, it was made immensely visible by the participation of major Internet players such as Google, Wikipedia, Reddit, Tumblr, Flickr, Wordpress, Mozilla, and Craigslist. In this respect, we could say that SOPA and PIPA prompted a unified response from the three strands of technolibertarianism outlined above because they posed a threat to the most fundamental property of information-its accessibility. Yet the motivations of the actors who participated in the protests differed from one another. For tech companies such as Google and Facebook the two bills not only threatened to increase the costs of policing their own websites for copyright-infringing material but, more importantly, of cutting the advertising revenues associated with such material (Wortham 2012b). In the case of user-generated websites such as Wikipedia, Reddit, and Tumblr, SOPA and PIPA threatened their contributors' ability to post links to potentially infringing websites and to discuss related content. Finally, advocacy groups such as the Electronic Frontier Foundation emphasized that the anti-piracy bills could be used to cut funding to pro-human rights projects and NGOs such as the Tor Project, EngageMedia, and Wikileaks, which facilitate access to information whose value lies primarily in its actionability (Timm 2011).

Further, it should be noted that the success of the protests was made possible precisely by the shareable and actionable nature of the information that publicized them. As Shirky points out, native features of the social web such as hashtags, embeds, and comments allow users to share information with one another, collaborate and undertake collective action with no need of centralized supervision $(2008,47-$ 53). Shirky's key insight is that by building cooperation into the infrastructure the social web has caused a vertical fall of the economic costs of coordinating group activity (Ibid., 18). Thus loosely organized networked collectives can easily outsmart institutional opponents that rely on a slow and costly managerial structure to direct employee activity. The SOPA-PIPA strike perfectly illustrates this point on both an economic and political level. On an economic level, the strike was nothing but a confrontation between corporations that tried to protect assets produced under an industrial organization of the value chain and corporations whose profitability depends instead on a networked organization of the value chain. On a political level, it is significant that, notwithstanding the massive resources invested in lobbying Congress, the copyright holders were completely unable to organize an effective response to the strike. In contrast, the tech companies had merely to endorse and amplify the visibility of the calls to action to bring large networks of loosely coordinated activists on their side.

To be sure, such observation risks of overshadowing the initiative of the activists, who first organized against the bills, prompting the tech companies to follow suit. At the same time, it is undeniable that large capital investments in the Internet infrastructure-especially in the interoperability of social media platforms and accessibility of rich content via mobile technologies-have enabled the real-time cooperation of large numbers of Internet users, which proved essential to the success of the SOPAPIPA strike. These investments, however, have a political cost. Whereas the distributed nature of the TCP/IP protocol allows users to establish relations of reciprocity and mutually define the norms that undergird their interactions, social network sites (SNSs) are centralized systems whose administrators can silence users with no need of explanation (Hands 2011, 83-91). In this sense, the activists' reliance on SNSs 
such as Facebook, Twitter, and Tumblr poses the problem of their autonomy from these platforms or, conversely, of the democratic control of SNSs.

Further, there are at least three additional critiques that are moved to social media activism. First, if it is true that SNSs have proved quite effective for coordinating protest movements such as the Arab Spring, 15-M, and Occupy (Gerbaudo 2012), authoritarian governments can easily use the very same platforms to track down activists and crush dissent (Morozov 2011). Second, SNSs are often accused of fostering "slacktivism," a form of participation that requires a low level of engagement and is virtually risk-free. Because SNSs are largely built around weak ties, that is, connections among strangers and acquaintances, they would not lend themselves to the kind of "high-risk activism" that is predicated on strong ties and a shared sense of responsibility among activists (Gladwell 2010). Third, the lack of a recognizable structure, membership, and leadership would make SNSs incapable of thinking and acting strategically (lbid).

In sum, the criticism of SNS-based activism can be condensed as a three-part argument: 1) SNSs are not sufficiently autonomous from governments and corporations to function as vectors of social change; 2) Activists have no control over the norms of conversation, the modes of interaction, nor the data and metadata generated by their activities in SNSs; 3) Political participation via SNSs typically lacks the kind of organization and leadership that drives successful political movements. In a way, the third part of this argument is only the most recent iteration of a long-running (Leninist) critique of social movements as insufficiently structured and organized. Or, from a perspective that is more sympathetic to social movements, this critique is nothing but a revamp of historic cautionary tales on the risk for activists to fetishize "structurelessness" (Freeman 1970). Yet addressing the problem of organization exclusively through these lenses risks to overlook the specificity of networked activism.

To begin with, as noted, the social web has collapsed the transaction costs of coordinating group effort, allowing for the quick propagation of calls to action on an unprecedented scale. Further, the social web has facilitated the cooperation between activist networks and emerging modes of "weak-tie" participation. Indeed, the calls to action that circulated via Facebook prior to the Egyptian Revolution of January 2011 were created and shared by both "average" Egyptians and organized political actors such as the April 6 Movement (Ghonim 2012). This has led some social movement theorists to argue for a more hybrid framework, which can grasp the relationship between weak-tie activism and strong-tie activism, spontaneity and organization, in dialectical rather than oppositional terms (Nunes 2012; Kioupkiolis 2014).

If this approach is useful to bypass dichotomies that do little to advance our understanding of networked social movements, it still fails to address the question of their autonomy from capital and the state. One way to approach this question is to contrast Web 2.0 activism to the Global Justice Movement's attempt to create an autonomous communication infrastructure. As we will see in the next section, the GJM was committed to the network as an ideal organizational form that could facilitate the convergence of a variety of actors on shared objectives, without compromising their autonomy. This ideal was inspired to a set of discursive practices, such as those of the Free and Open Source Software movement, which embodied the notion that a network can govern itself. My wager is that contemporary technopopulism arises from the intersection of these two trajectories, that is, from the activist and communalist strands of technolibertarianism. 


\section{The Global Justice Movement's Experiments in Networked Self-Government}

The alter-globalization movement acquired its global dimension through the interconnection of local and regional networks of autonomous spaces, unions and workerowned coops, activist listservs and websites, community radios, hacklabs, and the newborn Independent Media Centers (Juris 2008; Wolfson 2014). Although chronically underfunded and maintained through voluntary efforts, this sociotechnical infrastructure supported the emergence of a set of practices that were clearly autonomous from and antagonistic to transnational capital and the supranational governance of institutions such as the IMF, World Bank, and the WTO. It is therefore striking to see how this infrastructure was abandoned or migrated to commercial platforms in the mid-to-late 2000s. Some scholars have identified the causes of the decline of these networks in their overreliance on technology and related inability to build structured organizations rooted in class analysis (Wolfson 2014). Others have argued that the growing centrality of social media to political mobilizations has contributed to shape a new "populist" discourse, which rejects traditional Left/Right divisions of the political spectrum, and is materialized in an emerging "democracy 2.0" based on the measurement of social media preferences (Gerbaudo 2014).

Even though these two analyses are advanced from antipodal positions-MarxistLeninist and post-ideological or populist, respectively - they both criticize the Global Justice Movement (GJM) for being too self-referential and incapable of building a large support base. Whereas for the Marxist-Leninists the GJM was weakly organized and weakly linked to the working class, for the theorists of the 2011 popular wave the GJM was not transversal enough and thus unable to exert a culturalpolitical hegemony within society. As Laclau and Mouffe (1985) point out, the notion of hegemony presupposes a capacity to establish an articulatory nexus among a plurality of demands and subject positions in the struggle against a common enemy. Whether the working class is the subject endowed with the historical task to institute this nexus (as the Marxist-Leninists argue) or any subject can potentially take up this role (as the post-Marxists have it) is a problematic that exceeds the scope of this article. What matters, at least for the purpose of this argument, is that in establishing a relation of equivalence among dispersed subject positions and demands, hegemonic practices tend to "fix the meaning of the social in an organized system of differences" (Ibid, 135). As such, the notion of hegemony may not be suited to analyze social movements such as the GJM, the Indignados or Occupy that eschew the politics of demands, alliances, and coalition-building in favour of a "prefigurative politics" (Downing 2001), that emphasizes the creation of inclusive and egalitarian processes of participation and deliberation as harbingers of broader societal transformations.

This is all the more true when we consider that digital networks have only enhanced the capacity of groups and individuals for self-representation. To be sure, networked social movements still coalesce around shared grievances and objectives. But the pursuit of these objectives does not necessarily entail a subordination of difference to political and organizational unity. Rather, as Juris points out, the GJM followed a "networking logic" that entailed a commitment to decentralization, convergence, and autonomy:

While the command-oriented logic of traditional parties and unions involves recruiting new members, developing unified strategies, pursuing political hegemony, and organizing through representative structures, network politics revolve around the creation of "convergence spaces," 
where diverse collectives, organizations, and networks converge around a few common hallmarks, while preserving their autonomy and specificity (Juris 2008, 14).

Thus Juris' insight is that the GJM activists did not see the network as a mere communication infrastructure but as an emerging organizational form. Hardt and Negri make a similar point when they observe that the internal organization of resistance movements has progressively evolved towards the network form and that the project of constructing the multitude as a movement of movements "resembles an open and expansive network in which all differences can be expressed freely and equally" (2004, XIV).

The analogy between the distributed nature of the Internet and the inherently democratic nature of network politics can be puzzling because the Internet can support any sort of organization-including hierarchical and centralized ones. Indeed Juris cautions that "discourses of open networking often conceal other forms of exclusion based on unequal access to information or technology" (Ibid.). Academic research has also shown that unconstrained and rapidly growing networks such as the Internet are characterized by the emergence of "power-law distributions," which endow a few highly connected nodes with a disproportionate amount of power and visibility (Barabási 2002; Hindman 2008). Further, as we have seen, if Internet protocols such as the TCP/IP are distributed, others (such as the DNS) are centralized (Galloway 2004), allowing authorities to filter and censor undesired information.

The above considerations should serve as a healthy reminder that "hegemony qua unequal power and centralized control is an ever-present possibility of the multitude in its actual and conceivable instances" (Kioupkiolis 2014, 159). This is particularly true if we understand the construction of the multitude as an endeavour that requires the indispensable mediation of networked technical systems and thus of a technoelite that knows how to run, customize, and develop such systems. Nonetheless, at the time of the GJM, the network form functioned as a powerful ideal, we might even call it a Master Signifier, that inspired and gave meaning to the actions of an entire generation of activists. For example, in the early 2000s, the tech-savvy fringes of the GJM launched the European Social Consulta, an online platform modelled after the Zapatistas' consultation process that was supposed to scale assemblary and deliberative decision-making processes from a local to a regional and international level (Juris 2008, 282-285).

Even though the ESC proved to be an overly ambitious project, the idea of using the Internet to scale direct democracy and build participatory forms of governance from the ground up continues to this day. Indeed, the roots of contemporary technopopulism lie precisely in this notion that a network can govern itself. This is a far from obvious proposition as transnational sociotechnical networks often lack clearly defined constituencies. In contrast, the notion of governance presupposes the management (or self-management) of a bounded domain-which usually includes a population, a territory, and a set of resources. Perhaps it is no accident that all major experiments in online participatory democracy have occurred within parties that operate within specific national contexts. In other words, even though contemporary technopopulism is a transnational ideological orientation (Gerbaudo 2014), its actualization in national parties is in tension with the technolibertarian demand of a universal, postnational, and unregulated access to information. 


\section{The FOSS Mode of Governance and the Agonistic Politics of Forking}

I will return to the tension between the national and the universal in the discourse of technopopulism in the conclusion. For now, I would just notice that the notion of a self-governing network seemed a "plausible promise" (Raymond 1999) because it was inspired to an existing model of collaboration: the Free and Open Source Software (FOSS) development process. Many GJM activists looked in fact at the collaborative process whereby "geographically dispersed computers programmers" contribute code to nonproprietary software on a voluntary basis "as a model of political organizing and a potential harbinger of postcapitalist forms of economic, social, and political organizing" (Juris 2008, 16-17).

On an economic level, FOSS is a nonrival and nonexclusive good. Not only FOSS can be used without depleting (as any digital object), but is explicitly designed not to exclude anyone from studying, copying, modifying, and distributing the source code. In short, FOSS is a digital commons whose overabundance poses a challenge to capitalist accumulation, which is predicated on the exploitation of (artificial) scarcities. Such overabundance sets the conditions for a "commons-based" model of production that is alternative to the capitalist organization of labour in at least three respects: 1) Contributions to FOSS projects are by and large unpaid and voluntary; 2) Developers can contribute as much or as little as they want to each project; 3) FOSS engineers and principal developers constantly compete for the contributors' attention, time, and resources.

The voluntary nature of cooperation and the nonrival, nonexclusive nature of FOSS determines a specific mode of management and style of leadership. In particular, Linux distributions such as Debian and Ubuntu, open content encyclopedias such as Wikipedia, and large repositories of FOSS such as GitHub and Sourceforge allow anyone to copy existing code or content and use it as the basis for an alternate version of the same commons. To be sure, the threat of a "fork"-as FOSS programmers refer to the development of an independent version of existing software based on the same source code-is more potential than actual. Because forking involves a split within the base of contributors, prohibitions on forking operate as a social taboo within the FOSS community (Mako Hill 2005). At the same time, this constantly looming threat forces leaders to maintain a cooperative attitude so as not to alienate potential collaborators. From this point of view, forking is a "defining characteristic of FOSS" (Reagle 2010, 82) whose "constitutive nature" (Tkacz 2011, 86) for the open source mode of governance is evident on two distinct levels.

On a first level, the actual production of a fork "de-monopolizes power" (Bauwens $2005,96)$ and "simultaneously maximizes the freedom of individual participants" (Tkacz 2011, 97). On a second level, because forking involves a dissipation of resources, its very possibility "demands that whatever mode of rule or governance is adopted by a project, this mode must in the last instance be perceived by all members of the project as legitimate or else they will leave" (Ibid.). Thus the "right to fork" (Weber 2004, 159) informs the FOSS mode of governance regardless of whether or not a fork is actually implemented. In fact, the high costs of maintaining a large code base through voluntary contributions forces principal developers to search for consensus and collaboration rather than promoting decentralization and individual freedom (Famiglietti 2011). Obviously, searching for consensus does not mean that consensus is ever achieved. On the contrary, alternative forks of the same source code-whether potential or actual-compete for the attention and skills of the same base of contributors. 
If the political implications of this cooperative-competitive model are not new, recently they have begun to migrate from the governance of FOSS projects to the world of politics. The most significant example of this migration is LiquidFeedback, a decisionmaking software developed in 2009 that has been adopted by several Pirate Parties in Europe and across the world. LiquidFeedback has been closely associated with Liquid Democracy, an emerging decision-making protocol that mixes elements of direct democracy and representative democracy. Rather than assuming that all members of an organization or a political party are equally knowledgeable on every issue, LiquidFeedback (LF) lets participants decide whom to delegate on specific initiatives. Those who hold proxy votes can in turn transfer them to other delegates, facilitating the emergence of networks of trust. Such trust, however, is not a blank check as proxies can be revoked at any time so as to prevent the crystallization of power elites (Behrens et al. 2015).

In addition to implementing a reversible system of delegation, LF allows participants to propose amendments to existing political initiatives. If the author of an initiative refuses to amend it, other participants can fork it, that is, create an amended proposal that will compete with the original one in the voting phase. Additionally, voting does not follow the principle of majority rule or first-past-the-post, but is based on the Schulze method, a pairwise comparison voting system that allows participants to rank candidates and initiatives in order of preference (Schulze 2011). Similar to the practice of forking, the Schulze method has been used to make decisions about the direction of Linux distributions such as Debian, Ubuntu, and Gentoo, as well as to elect delegates and representatives within organizations such as the Free Software Foundation and the Wikimedia Foundation.

Thus we can see how a certain procedural knowledge has been migrating from the FOSS world to the realm of institutional politics-and in particular to those parties that have espoused the open source philosophy and its collaborative ethos. To be sure, political initiatives are neither computer programs nor Wikipedia articles. In fact, the problems software developers and software engineers try to solve are always specific to a technical world and cannot be transferred ipso facto to society as a whole (Dean 2010). Conversely, the wide range of problems faced by a political community such as a party or a social movement cannot be simply solved through technological solutions (Morozov 2013).

Nonetheless, this migration of a mode of governance from the world of open source programming to institutional politics is a phenomenon that has significant political implications. For example, the developers of LF believe that networked information technologies can help correct many democratic deficits in political parties, including lack of accountability, lack of transparency, lack of participation, or excessive centralization (Behrens et al. 2015). By thrusting ideas rather than leaders into the centre of the political process, allowing those ideas to compete with one another, and adopting voting procedures that are supposedly transparent and democratic, $L F$ presents itself as the diagram of an emerging mode of governance that is technocratic, leaderless, agonistic, meritocratic, and universalist.

Thus the leaderless-technocratic variant of technopopulism believes that democratic self-government can be achieved through the application of a standardized procedure to large-scale decision-making processes. Similar to the GJM's belief that a network can govern itself, this variant assumes that the social intelligence of the network is higher than any individual contribution and any leader's competence or charisma. Unlike the GJM, however, this brand of technopopulism does not privilege social movements as the driver of democratic participation and popular sovereignty. 
Rather, political organizations are invited to free the social intelligence of the network by adopting rational and carefully designed decision-making processes. It is worth noting that in the case of LF this social intelligence is harnessed through the staging of a competition among alternative proposals, which might only slightly differ from one another.

From the point of view of political theory, this agonistic politics of forking resonates with Chantal Mouffe's definition of agonistic democracy (2005) as a competition among adversaries within a shared symbolic space. Yet the imagined conditions of a technology-enabled agonistic democracy do not necessarily match their practical implementation. Indeed, the use of LF hasn't yielded the hoped for results-at least at the level of party organizing. For example, some have pointed out that in spite of its emphasis on decentralization and reversibility, LF's delegation system favours the concentration of proxies in few hands (Becker 2012). Further, the implosion of the German Pirate Party after its electoral success of 2011, and the limited penetration of small techno-parties such as Partido X (Spain), Partido de La Red (Argentina), Wikipartido (Mexico), as well as dozens of Pirate Parties around the world, may epitomize the inability of the leaderless variant of technopopulism to synthesize different positions in a coherent and recognizable political line (Deseriis 2015). By contrast, parties that have endowed a ruling group with the task of making decisions at the highest level have been far more successful than these parties in the electoral arena. I shall therefore now briefly consider this second strand of technopopulist parties before reaching my conclusion.

\section{The Leaderist Variant of Technopopulism and the Cybercratic Politics of Unity}

As noted, technopopulism emerges from the encounter of technolibertarian discourse and populist discourse. Even though these formations are historically distinct-as modern populism preexists technolibertarianism by several decades-there are many common elements that allow for their convergence and hybridization. As we have seen, technolibertarians harbour a deep distrust in bureaucratic and hierarchical forms of authority, which would pose a threat to the unrestrained circulation of information. Further, technolibertarians believe that digital information should be easily shareable, editable, and actionable, so as to allow ordinary Internet users to cooperate and take matters into their own hands. We have also seen how the growing automation of networked cooperation allows for the rapid scaling of political campaigns, which can be organized by loosely coordinated groups of Internet activists outside of institutional affiliations. Finally, the notion that a network can govern itself is embedded in GJM's early experiments in networked self-government, the open source mode of governance, and its extension to political parties that have opened their decision-making processes to the direct input of their members.

Whereas these elements indicate that technolibertarianism and technopopulism share many features, the latter would have never acquired its current status without the global financial crisis of 2008 and the popular wave of protest movements that began in 2011. As is known, the popular wave was fuelled by widespread frustration at corrupted political elites, soaring unemployment rates, austerity measures, and growing wealth inequality. In countries like Egypt, Spain, Greece, United States, Israel, and Turkey, protest movements have chosen the tactic of occupation of public space and the setting of encampments in public squares. The mass diffusion of social network sites-which did not exist at the time of the GJM-has provided both an outlet for the expression of popular dissent and for mobilizing ordinary citizens disaf- 
fected with traditional party politics. As previously noted, the mass diffusion of social network sites has allowed organizers to mobilize Internet users who were unreachable by the self-referential activist networks of the GJM. The combination of highly visible occupations, encampments, and mass assemblies with the popularity of social media has thus produced a distinctive protest culture, whose discourse focuses on unity and whose majoritarian vocation is epitomized by the Occupy slogan "We are the 99\%." Understandably, the popular wave's focus on aggregation (Juris 2012), the rejection of political representation (Sitrin and Azzellini 2014) and of traditional LeftRight divisions of the political spectrum, has prompted scholars to label these movements as populist (Gerbaudo 2012; 2014).

Even though populist movements vary greatly depending on their ideological traits, socioeconomic composition, and regional features, most scholars agree that populism can be generally described as an antagonistic discourse that pits the people against the establishment (Canovan 1999; Panizza 2005; Laclau 2005a). This general definition has its limitations in that both the people and the establishment are vague political concepts. In fact, the ambiguity of the people as a political category is already inscribed in its etymology as "the people can be conceived as populus, the body of all citizens; or as plebs, the underprivileged." (Laclau 2005a, 81). According to Laclau, populism begins when the underprivileged claim to be the only legitimate populus by establishing a chain of equivalence among different demands and subject positions (Ibid.). Whereas the ruling class of a functioning democracy is able to address selectively the demands that emerge from the social field, the formation of a popular subject signals for Laclau that partial struggles and mobilizations are no longer absorbed differentially within the system. In this sense, the movements of the popular wave express the emerging solidarity of social demands and subjectivities that share the opposition to a common enemy.

Whereas in countries like Tunisia and Egypt this social solidarity was powerful enough to overthrow the government, the economic recovery in the United States has allowed for a partial reabsorption of these social demands within the traditional system of party politics (e.g. through the presidential bids of anti-establishment candidates such as Bernie Sanders and Donald Trump). In Southern Europe, the prolonged recession and stagnation that followed the financial crisis has created instead favourable conditions for the rise of new political formations such as Syriza, Five Star Movement, and Podemos. From the social movements of 2011, these "movementparties" have borrowed a strong anti-establishment stance and a radical participatory ethos. Similar to the Pirate Parties, M5S and Podemos have made an extensive use of information technologies to empower their party base, employing a vast array of software tools that allow their members to discuss and draft policy proposals, hold primaries online, crowdfund initiatives and campaigns, screen their elected representatives' expenses, and even vote on decisions that are yet to be taken in Parliament.

Unlike the leaderless variant of technoparties, however, M5S, Podemos, and Syriza are all led by clearly recognizable, telegenic, and charismatic leaders. On a first level, the electoral successes of these parties can be explained with the fact that TV and audiovisual media still play a central role in forming the public opinion. And Beppe Grillo, Pablo Iglesias, and Alexis Tsipras' "virtuosity" in performing before large audiences (Virno 2004, 52) allows them to reach out to sectors of the electorate who do not have the interest, time, or skills to participate in networked politics. On a second level, these leaders perform the critical function of conferring unity and identity to their parties by setting them in opposition to the traditional political establishment. For example, at the first Congress of Podemos, Pablo Iglesias motivated the 
reason for appointing only one Secretary General, himself, at the helm of the party rather than three (as suggested by his political opponents) with the need for Podemos of having one recognizable leader who could challenge and defeat the leaders of the Popular Party and the Socialist Party. Similarly, Beppe Grillo and the recently departed Gianroberto Casaleggio have strategically positioned the M5S at the centre of the Italian political spectrum in spite of progressive and Leftist pressures coming from the M5S activist base.

The leadership's role in imparting unity and a strategic direction to these parties is also evident from the unresolved question of the actual power that is to be attributed to online decision-making. In the case of Podemos, after an initial attempt to develop the party program through Plaza Podemos-a discussion board enabled by the social news site Reddit-the online participatory drive has been mostly confined to the use of the application Agora Voting for the party primaries and the adoption of the decision-making software Loomio at a local level. Whereas the latter is built upon the consensual decision-making protocols of the 15-M and Occupy assemblies (as Loomio gives each participant the right to veto any proposal), the software has little capacity to scale participation from a local to a national level. In the case of the Five Star Movement, the party derives its very name from the five policy areas-Water, Environment, Transportation, Connectivity, and Development-that were originally defined through online discussions in 2009, when hundreds of Meetup groups provided the organizational backbone of the nascent movement-party. At the same time, the Beppe Grillo blog, the Web portal movimento5stelle.it, and more recently the platform Rousseau constitute centralized hubs where M5S members are consulted on critical Parliamentary decisions that are to be taken by the MPs, and can participate in the drafting of regional, national and European laws (Deseriis 2016). The collaboration between local, regional, and the national cadres, however, has also been fraught with tension as the Casaleggio Associati - the company that manages the M5S Web server - has often been accused of little transparency and centralization (Mosca 2015).

From this angle, we could say that the Southern European way to technopopulism agitates the promise of networked democracy only to frustrate it with centralized decisions that foreclose demands for more participation and inclusion that emerge from the netroots. Yet it would be reductive to read centralization as the true and therefore only face of Southern European technopopulism. On the contrary, as Laclau points out, the hegemonic articulation of differential demands in and through the name of a populist leader presupposes difference and is inseparable from it (Laclau 2005b, 46). In this respect, it is no accident that the leaderships of M5S and Podemos openly encourage networked participation so as to extract important political indications from it. In other words, these Southern European parties free the social intelligence of the network and simultaneously channel it through ongoing online consultations. Thus, if cyberocracy is the "rule by way of information" (Ronfeldt 1992), then M5S and Podemos have developed a cybercratic politics of unity, which enables grassroots initiatives insofar as they do not interfere with decisions that are made at the highest level.

At the same time, in guaranteeing a retroactive unity (Žižek 1989) to instances that would otherwise remain separate from one another, the name of the leader performs the critical function of suturing an heterogeneous discursive space while allowing it to enter the field of political representation. In this sense, the electoral successes of the leaderist variant of technopopulism can be explained with a realistic understanding of the electoral competition as an intrinsically reductive and thus hegemonic practice. This hegemonic aspect, it should be noted, is irreconcilable with the GJM's aspiration 
to build a self-governing network of communities that could redefine the notion of sovereignty beyond electoral politics and national boundaries.

\section{Conclusion}

In sum, in this article I have argued that contemporary technopopulism is a discursive formation or a materialized ideology that is predicated upon the belief that "the government of the people, by the people, for the people" is achievable by means of networked information technologies. This discursive formation emerges from the convergence and hybridization of two distinctive discourses: technolibertarianism and populism. Technolibertarianism is a stratified discursive formation that incorporates three distinct strands - capitalist, communalist, and activist. The social web's automation of cooperation has allowed for the activist and communalist strands to coordinate massive political campaigns such as the Internet Blackout and to experiment with increasingly sophisticated decision-making processes for the management of digital commons. Even though the lack of autonomy of social media activism from the commercial platforms that enable it should be a matter of serious concern to activists, the mass diffusion of social network sites has allowed them to reach ordinary citizens, which were by and large unreachable by the self-referential networks of the GJM. At the same time, the GJM experimentation with networked forms of selfgovernment has anticipated many political experiments to come. Indeed, the idealistic notion that society can govern itself from below as a network of networks, combined with the actual governance of large open source projects, and the popular wave of protest movements that begun in 2011, has inspired a new generation of technoparties, which try to reconcile the open, decentralized, and participatory nature of networked activism with electoral politics.

These parties can be divided in two main variants: a leaderless-technocratic variant whose anti-establishment stance is embedded in an emerging mode of governance derived from the open source world; and a leaderist-cybercratic variant wherein charismatic leaders confer unity to their parties by synthesizing different positions that emerge from the network to mobilize them against the establishment. Even though these two variants seem to embody irreconcilable tendencies, from a discursive point of view, they complement each other. Decentralization and forking are in fact politically productive only insofar as they occur within a shared discursive space that is bounded and strategically oriented. And centralized management is effective only insofar as it does not obliterate differences, but allows them to express themselves while having a vision of the whole.

Yet the two variants code their anti-establishment messages differently. The leaderless variant sees in fact the Network as the empty signifier for a radically participatory model of democracy, which should allow lay citizens to introduce, deliberate, and vote on legislation directly, that is, outside of the mediation of political parties. In this sense, the (utopian) project of a fully realized digital direct democracy entails nothing less than the demise of the professional class of politicians, the end of political representation, and "the abolition of all political parties" (Weil 2013), which would become redundant vis-à-vis networked self-government.

Significantly, these utopian elements are also present within the discourse of the leaderist variant of technopopulism. In fact, both Podemos and M5S disdainfully refer to career politicians as members of a self-serving "casta" and endow the network with the task of returning power to ordinary citizens. The M5S goes as far as presenting itself as a "non-party" regulated by a "non-statute" that openly denies the autonomy of candidates and elected representatives from their constituents' will (Del Savio and 
Mameli 2014). Further, the leaders of M5S and Podemos have attributed themselves the critical task of developing a political line that brings together a plurality of demands and subject positions through a strong anti-establishment stance. As we have seen, this hegemonic articulation passes through the name of a leader, a signifier whose tendency towards an abstract and "empty" universality increases with the progressive extension of the equivalential logic to realities that have little in common with one another (Laclau 2005b, 39-40).

Yet in lending a proper name to the network of citizens who refuse representation, the leader becomes necessarily exposed to the pressures that emerge from the network for self-representation. In this sense, we could say that the challenge for the technopopulisms to come is to open up the unifying function of the name of the leader to manifold uses, without letting such uses undermine such function. In other words, it is only when the name of the leader is understood as an abstract function whose symbolic and decisional power is made available to networked decisionmaking, that technopopulism will be able to merge technolibertarianism and populism in an assemblage that is more than the sum of its parts. At the moment, the presence of centralizing and charismatic leaders on one side, and the difficulty of constructing the Network as an empty signifier for a fully realized democracy on the other side, makes the distinction between the two variants significant both in analytical and political terms. Differently put, if the discourse of technopopulism emerges from an ensemble of differential positions, as a political project technopopulism cannot fully solve the tension between its constitutive components: the pluralistic nature of networks and the totalizing tendency of populism.

This constitutive tension mirrors a second tension that I have identified earlier onnamely, the tension between the national dimension of populism and the universalism of technolibertarianism. Whereas popular sovereignty is inherently exclusive (as the people define themselves in opposition to an other) and technolibertarianism is inherently inclusive (as access to information is a universal human right) the tension between the people and humanity is not an irresolvable contradiction, but a paradox that lies at the heart of modern democracy (Mouffe 2005). If the most successful technopopulist experiments of the early twenty-first century have privileged popular sovereignty, the question remains open as to whether the leaderless variant will be able to develop a robust vision, ethos, and actionable party programs that will propel libertarian technopopulism beyond its current niche position.

\section{References}

Althusser, Louis. 1971. Ideology and Ideological State Apparatus. In Lenin and Philosophy and Other Essays, 121-176. New York: Monthly Review Press.

Barabási, Albert László. 2002. Linked: How Everything Is Connected to Everything Else and What It Means for Business, Science, and Everyday Life. New York: Perseus Books.

Barbook, Richard and Andy Cameron. 2014. The Californian Ideology (1995). In The Internet Revolution, edited by Richard Barbrook with Andy Cameron, 12-27. Amsterdam: Institute of Network Cultures.

Barlow, John Perry. 1996. A Declaration of the Independence of Cyberspace, Electronic Frontier Foundation website. Accessed May 26, 2016. https://www.eff.org/cyberspaceindependence

Bauwens, Michel. 2005. P2P and Human Evolution: Peer to Peer as the Premise of a New Mode of Civilization. Accessed May 26, 2016.

http://www.altruists.org/static/files/P2P\%20and\%20Human\%20Evolution\%20(Michel\%20B auwens).pdf 
Becker, Sven. 2012. Liquid Democracy: Web Platform Makes Professor Most Powerful Pirate. Accessed May 26, 2016. http://www.spiegel.de/international/germany/liquiddemocracy-web-platform-makes-professor-most-powerful-pirate-a-818683.html

Behrens, Jan, Axel Kistner, Andreas Nitsche, Björn Swierczek, and Marco Deseriis. 2015. Liquid Democracy, Its Challenges and Its Forebears. OpenDemocracy. Accessed May 26, 2016. https://www.opendemocracy.net/can-europe-make-it/jan-behrens-axel-kistnerandreas-nitsche-bj\%C3\%B6rn-swierczek-marco-deseriis/liquid-de

Boltanski, Luc and Ėve Chiapello. 2006. The New Spirit of Capitalism. London: Verso.

Brand, Stewart. 1985. 'Keep Designing': How the Information Economy Is Being Created and Shaped by the Hacker Ethic. Whole Earth Review 46 (May 1985): 44-55.

Canovan, Margaret. 1999. Trust the People! Populism and the Two Faces of Democracy. Political Studies 47 (1): 2-16.

Clark, David. 1992. A Cloudy Crystal Ball: Visions of the Future. Plenary Presentation at the $24^{\text {th }}$ Meeting of the Internet Engineering Task Force, Cambridge, MA, July 13-17, 1992. Accessed May 26, 2016. http://groups.csail.mit.edu/ana/People/DDC/future ietf 92.pdf

Coleman, E. Gabriella. 2013. Coding Freedom: The Ethics and Aesthetics of Hacking. Princeton, $\mathrm{NJ}$ : Princeton University Press.

Dean, Jodi. 2010. Blog Theory: Feedback and Capture in the Circuits of Drive. Cambridge: Polity.

Del Savio, Lorenzo and Matteo Mameli. 2014. Anti-representative Democracy: How to Understand the Five Star Movement. OpenDemocracy. https://www.opendemocracy.net/caneurope-make-it/lorenzo-del-savio-matteo-mameli/antirepresentative-democracy-how-tounderstand-fi

Deseriis, Marco. 2015. Podemos' Dilemma and Why Leadership Still Matters. OpenDemocracy. Accessed May 26, 2016. https://www.opendemocracy.net/can-europe-makeit/marco-deseriis/podemos\%E2\%80\%99-dilemma-and-why-leadership-still-matters

Deseriis, Marco. 2016. A Preliminary Analysis of the Political Values Embedded in Rousseau, the Decision-Making Platform of the Five Star Movement (Parts I and II). Accessed October 27, 2016. https://scalingdemocracy.net

Downing, John D. H. 2001. Radical Media: Rebellious Communication and Social Movements. London: Sage.

Dyson, Esther, George Gilder, George Keyworth, and Alvin Toffler. 1994. Cyberspace and the American Dream: A Magna Carta for the Knowledge Age. Future Insight. 1.2. The Progress \& Freedom Foundation.

Famiglietti, Andrew. 2011. The Right to Fork: A Historical Survey of De/centralization in Wikipedia. In Critical Point of View: A Wikipedia Reader, edited by Geert Lovink and Nathaniel Tkacz. 296-308. Amsterdam: Institute of Network Cultures.

Foucault, Michel. 1972. The Archaeology of Knowledge. London: Tavistock.

Freeman, Jo. 1970. The Tyranny of Structurelessness. Accessed May 26, 2016. http://www.jofreeman.com/joreen/tyranny.htm

Galloway, Alexander. 2004. Protocol: How Control Exists After Decentralization. Cambridge, Mass.: MIT Press.

Gerbaudo, Paolo. 2012. Tweents and the Streets: Social Media and Contemporary Activism. London: Pluto.

Gerbaudo, Paolo. 2014. Populism 2.0: Social Media Activism, the Generic Internet User and Interactive Direct Democracy. In Social Media, Politics and the State: Protests, Revolutions, Riots, Crime and Policing in the Age of Facebook, Twitter and YouTube, edited by Daniel Trotter and Christian Fuchs, 67-87. London: Routledge.

Ghonim, Wael. 2012. Revolution 2.0: the power of the people is greater than the people in power: a memoir. New York: Houghton Mifflin Harcourt.

Gibson, William. 1984. Neuromancer. New York: Ace Books.

Gladwell, Malcolm. 2010. Small Change, The New Yorker. Accessed May 26, 2016. http://www.newyorker.com/magazine/2010/10/04/small-change-malcolm-gladwell 
Habermas, Jurgen. 1984. The Theory of Communicative Action, Volume One: Reason and the Rationalization of Society. Boston: Beacon Press.

Hands, Joss. 2011. @ Is for Activism: Dissent, Resistance and Rebellion in a Digital Culture. London: Pluto.

Hardt, Michael and Antonio Negri. 2004. Multitude: War and Democracy in the Age of Empire.

Hindman, Matthew. 2008. The Myth of Digital Democracy. Princeton, NJ: Princeton University Press.

Johnson, Steven. 2001. Emergence: The Connected Lives of Ants, Brains, Cities and Software. New York: Scribner.

Juris, Jeffrey S. 2008. Networking Futures: The Movements against Corporate Globalization. Durham, NC: Duke University Press.

Juris, Jeffrey S. (2012). Reflections on \#Occupy Everywhere: Social media, public space, and emerging logics of aggregation. American Ethnologist, 39: 259-279.

Kelly, Kevin. 1994. Out of Control: The New Biology of Machines, Social Systems, and the Economic World. New York: Basic Books.

Kioupkiolis, Alexsandros. 2014. A Hegemony of the Multitude: Muddling the Lines. In Radical Democracy and Collective Movements Today: The Biopolitics of the Multitude versus the Hegemony of the People, edited by Aleksandros Kioupkiolis and Giorgios Katsembekis. 149-68. Farnham and Burlington, VT: Ashgate.

Laclau, Ernesto. 2005a. On Populist Reason. London and New York: Verso.

Laclau, Ernesto. 2005b. Populism: What's In a Name? In Populism and the Mirror of Democracy, edited by Francisco Panizza. 32-49. London and New York: Verso.

Laclau, Ernesto and Chantal Mouffe. 1985. Hegemony and Socialist Strategy: Towards a Radical Democratic Politics. London: Verso.

Levine, Fredrick, Christopher Locke, Doc Searls, and David Weinberger. 2001. The Cluetrain Manifesto: The End of Business as Usual. New York: Perseus Books.

Lincoln, Abraham. 1953 [1863]. Address Delivered at the Dedication of the Cemetery at Gettysburg. In Collected Works of Abraham Lincoln, Vol. 7, edited by Roy P. Basler. 18-23. New Brunswick, NJ: Rutgers University Press.

Mako Hill, Benjamin. 2005. To Fork or Not to Fork: Lessons from Ubuntu and Debian. Accessed May 26, 2016. https://mako.cc/writing/to fork or not to fork.html

Markoff, John. 2005. What the Dormouse Said: How the Sixties Counterculture Shaped the Personal Computer Industry. New York: Penguin.

Morozov, Evgeny. 2011. The Net Delusion: The Dark Side of Internet Freedom. New York: Public Affairs.

Morozov, Evgeny. 2013. To Save Everything Click Here: The Folly of Technological Solutionism. New York: Public Affairs.

Mosca, Lorenzo. 2015. Problemi e limiti del modello organizzativo "cybercratico" nell'esperienza del Movimento 5 Stelle [Problems and Limitations of the "Cybercratic" Organizational Model in the Five Star Movement Experience]. Ragion Pratica 44: 37-52.

Mouffe, Chantal. 2005. The Democratic Paradox. London and New York: Verso.

Netburn, Deborah. 2012. Wikipedia: SOPA Protest Led 8 Million to Look Up Reps in Congress, Los Angeles Times. Accessed May 26, 2016. http://latimesblogs.latimes.com/technology/2012/01/wikipedia-sopa-blackoutcongressional-representatives.html

Nunes, Rodrigo. 2012. The Lessons of 2011: Three Theses on Organisation. Mute magazine. Accessed May 26, 2016. http://www.metamute.org/editorial/articles/lessons-2011three-theses-organisation

Panizza, Francisco. 2005. Populism and the Mirror of Democracy. London and New York: Verso.

Raymond, Eric S. 1999. The Cathedral and the Bazaar: Musings on Linux and Open Source by an Accidental Revolutionary. Sebastopol, CA: O'Reilly Media. 
Reagle, Joseph. 2010. Good Faith Collaboration: The Culture of Wikipedia. Cambridge, MA: MIT Press.

Ronfeldt, David. 1992. Cyberocracy Is Coming. Santa Monica, CA: Rand Corporation.

Schulze, Markus. 2011. A New Monotonic, Clone-Independent, Reversal Symmetric, and Condorcet-Consistent Single-Winner Election Method. Social Choice and Welfare 36 (2): 267-303.

Shirky, Clay. 2008. Here Comes Everybody: The Power of Organizing without Organizations. New York: Penguin.

Sitrin, Marina and Dario Azzellini. 2014. They Can't Represent Us: Reinventing Democracy from Greece to Occupy. London: Verso.

Timm, Trevor. 2011. Proposed Copyright Bill Threatens Whistleblowing and Human Rights. Electronic Frontier Foundation (website), November 2, 2011. https://www.eff.org/deeplinks/2011/11/proposed-copyright-bill-threatens-whistleblowingand-human-rights

Tkacz, Nathaniel. 2011. The Politics of Forking Paths. In Critical Point of View: A Wikipedia Reader, edited by Geert Loving and Nathaniel Tkacz, 94-109. Amsterdam: Institute of Network Cultures.

Turner, Fred. 2006. From Counterculture to Cyberculture: Stewart Brand, the Whole Earth Network and the Rise of Digital Utopianism. Chicago: Chicago University Press.

Virno, Paolo. 2004. A Grammar of the Multitude. Los Angeles: Semiotext(e).

Weber, Steven. 2004. The Success of Open Source. Cambridge, MA: Harvard University Press.

Weil, Simone. 2013. On the Abolition of All Political Parties. New York: New York Review of Books.

Wolfson, Todd. 2014. Digital Rebellion: The Birth of the Cyber Left. Springfield: University of Illinois Press.

Wortham, Jenna. 2012a. Public Outcry Over Antipiracy Bills Began as Grass-Roots Grumbling, New York Times. Accessed May 26, 2016.

http://www.nytimes.com/2012/01/20/technology/public-outcry-over-antipiracy-bills-beganas-grass-roots-grumbling.html

Wortham, Jenna. 2012b. A Political Coming of Age for the Tech Industry. New York Times, Accessed May 26, 2016. http://www.nytimes.com/2012/01/18/technology/web-wideprotest-over-two-antipiracy-bills.html

Žižek, Slavoj. 1989. The Sublime Object of Ideology. London and New York: Verso.

\section{About the Author}

Marco Deseriis

Marco Deseriis is Assistant Professor in the Program of Media and Screen Studies at Northeastern University and Marie Curie Fellow at the Institute of Humanities and Social Sciences at the Scuola Normale Superiore in Florence. Titled Scalable Democracy, and based on an extensive set of semi-structured interviews with software developers and software users, his current research project analyzes the political values embedded in the affordances of a new generation of decision-making software and their use within parties such as Podemos, Five Star Movement, and the Pirate Parties. Deseriis' research also explores cultural and political dimensions of Internet-based activism, the emergence of new forms of subjectivity in the network society, and genealogies of experimental forms of authorship. His book Improper Names: Collective Pseudonyms from the Luddites to Anonymous (University of Minnesota Press, 2015) brings together some of these threads by examining the contentious politics and the struggles for control of a shared alias from the early nineteenth century to the age of networks. 